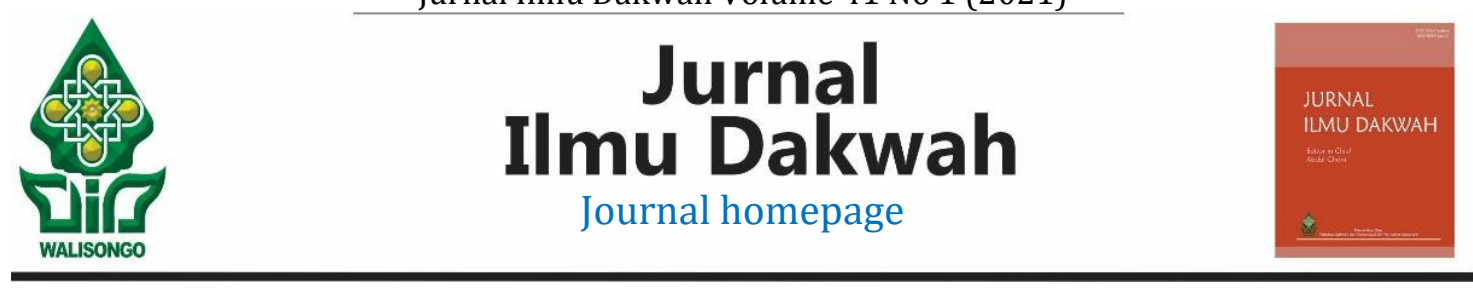

\title{
Dinamika dakwah Islam di era modern
}

\author{
Awaludin Pimay 1), Fania Mutiara Savitri ${ }^{2)}$ \\ 1,2Universitas Islam Negeri Walisongo Semarang \\ 1Email: pimay.awaludin@yahoo.co.id \\ 2Email: faniamutiara@walisongo.ac.id
}

\begin{abstract}
The development of science and technology has had an impact on the ethical joints of Muslims in this modern era. To anticipate the complexities of modern society, the da'i must prepare da'wah strategies and materials that are more directed at anticipating the tendency of society. Modernization in the midst of onslaught and globalization that takes place very quickly and it is difficult to predict the direction of the da'i must be carried out continuously effectively. This study aims to review effective da'wah strategies in the midst of changing da'wah dynamics. The research method used is descriptive qualitative research with the data collection technique is literature study. The literature study method is an activity related to the method of collecting library data, reading and taking notes and managing research materials. The results of the study indicate that da'wah can play an active role in the modern era if the da'i as a preacher is can participate development of the times so that da'wah as an illuminator is able to give a role to a society that deifies science and technology. In addition, da'i in modern life, da'wah must be directed to mad'u with the "bil wisdom wal mauizah hasanah" approach and with the use of media (bi al-tadwin). This step is also balanced with the da'i -both individuals and groups who qualified, have broad knowledge and insight, master da'wah materials, methods, and media that are appropriate and relevant to the conditions and progress of modern society they face.
\end{abstract}

Keywords: dynamics, da'wah, modern.

\begin{abstract}
Abstrak
Perkembangan ilmu pengetahuan dan teknologi telah membawa dampak berarti pada sendi-sendi etika umat Islam di zaman modern ini. Untuk mengantisipasi kompleksitas masyarakat modern da'i harus mempersiapkan strategi dan materi dakwah yang lebih mengarah pada antisipasi sebagai kecenderungan masyarakat. Di tengah terpaan modernisasi dan globalisasi yang berkembang sangat cepat dan sulit untuk di tebak arahnya da'i harus dilakukan secara terus menerus secara efektif. Penelitian ini bertujuan untuk meninjau strategi dakwah yang efektik ditengah-tengah dinamika dakwah yang terus berubah. Metode penelitian ini adalah kualitatif deskriptif dengan menggunakan teknik pengumpulan data melalui studi literature. Metode studi literature adalah serangkaian kegiatan yang berkenaan dengan metode pengumpulan data pustaka, membaca dan mencatat serta mengelola bahan penelitian. Hasil penelitian menunjukkan bahwa dakwah
\end{abstract}


dapat berperan aktif di era modern jika da'I sebagai pendakwah mampu ikut serta dalam perkembangan zaman sehingga dakwah sebagai penerang mampu memberi peran pada masyarakat yang mendewakan ilmu pengetahuan dan teknologi. Selain itu da'I dalam kehidupan modern, dakwah harus berorientasi kepada mad'u dengan pendekatan "bil hikmah wal mauizah hasanah dan dengan pemanfaatan media (bi al-tadwin). Langkah tersebut juga dimbangi dengan para $d a^{\prime} I$ baik individu maupun kelompok yang berkualitas, mempunyai pengetahuan serta wawasan yang luas, menguasai materi atau pesan dakwah, metode, dan media yang tepat dan relevan dengan kondisi dan kemajuan masyarakat modern yang dihadapinya.

Kata Kunci: dinamika, dakwah, modern.

\section{PENDAHULUAN}

Kemajuan ilmu pengetahuan dan teknologi telah menyebabkan terjadinya perubahan nilai, baik nilai positif maupun nilai negatif. Melalui perpaduan budaya Islam dan budaya Barat, seseorang dapat melihat nilai-nilai positif dan memperkaya nilai budaya Islam melalui bukti ilmiah dan teknis. Selain itu, pengaruh negatif tersebut diantaranya yakni turunnya nilai-nilai moral sebagian kalangan umat Islam, yang cenderung mengadopsi dan menggunakan tradisi budaya Barat yang tidak disertai penyaringan dahulu (Alhidayatillah N., 2018). Dalam masyarakat modern, kebebasan pribadi, toleransi keyakinan pribadi dan manajemen gaya hidup menjadi semakin unggul. Pada saat yang bersamaan, aspek kehidupan yang dikendalikan melalui kesadaran kolektif menjadi semakin terpinggirkan serta tereduksi.

Diasumsikan bahwa masyarakat pasif dalam mencampur adukkan urusan pribadi yang semakin meluas. Terdapat nilai-nilai yang mulai memudar karena adanya individualisme, seperti nilai gotong rotong. Beberapa Kegiatan yang sebelumnya dikerjakan oleh masyarakat secara bersama-sama (gotong royong) saat ini sudah diserahkan kepada penyedia jasa. Dalam tataran kehidupan yang semakin mendunia, perubahan-perubahan tersebut akan dimaknai sebagai suatu tradisi akibat pesatnya perkembangan teknologi dan komunikasi. Fenomena tersebut muncul dalam kehidupan sosial modern menambah warna kehidupan mereka dengan fenomena baru yang disebut era global. Gaya hidup modern telah menambah warna dalam kehidupan manusia, baik itu cara berpakaian, makan, berbicara, kebebasan membeli, pilihan restoran, pilihan hiburan, tata rambut, fashion, dan sebagainya. Gaya hidup seperti ini merupakan kombinasi dan keseluruhan dari bentuk, susunan, kebiasaan pilihan, dan benda-benda yang mendukungnya.

Perubahan nilai agama dan budaya menimbulkan ketidaknyamanan dalam kehidupan bermasyarakat. Banyak penyakit masyarakat yang semakin parah dari hari ke hari, seperti kemiskinan, pencurian, alkohol, narkoba, seks bebas, dll. Upaya mengantisipasi masalah ini tidak bisa lagi dilakukan melalui dakwah konvensional, hanya melalui mimbar. Namun dakwah harus menyentuh mereka secara langsung dengan cara-cara baru. Salah satunya dapat dilakukan melalui pendekatan dakwah yang memiliki inovasi. Salah satu bentuk inovasi yang dapat dilakukan adalah melalui dakwah yang dinamis dan lebih menerapkan pendekatan terhadap hal-hal yang lebih modern.

Memahami suatu konsep modern menjadi lebih mudah apabila ditelusuri dari kata yang mendasar. Secara etimologis, istilah modern asalnya dari bahasa latin "moderna" yang 
artinya sekarang, era baru atau pada saat ini. Karena hal itu, manusia disebut modern dalam pola kehidupan sadarnya. Dalam bahasa Indonesia, kata modern merupakan suatu kata sifat, dimana dalam tata bahasa (baca: bahasa Indonesia) kata sifat apabila ditambah dengan "isasi" artinya memiliki makna proses, maka modernisasi adalah suatu proses menuju modern. Kata sifat tersebut memiliki arti lain ketika "isme" yang ditambahkan. Karena menunjukkan suatu paham, suatu keyakinan atau suatu aliran, maka modernisme memiliki arti yang memahami modernitas. Jika telah direduksi menjadi suatu paham (baca: modernisme), maka cenderung mengarah pada unsur nilai di dalamnya sebagai ideologis. Ideologi modern ini nantinya akan berkembang menjadi gerakan modernisasi.

Namun hal yang harus diperhatikan adalah modernitas bukan hanya tentang waktu, melainkan juga tentang langkah atau pembaharuan. Artinya, seseorang bukan hanya menjadikan masa kini sebagai dasar kesadarannya, tetapi juga harus memiliki pola pikir dalam hidupnya. Karena modernisasi cenderung secara implisit merupakan proses di mana komitmen pola lama mulai terkikis, maka pola-pola baru diperkenalkan dan pola-pola baru tersebut diberi status modern.

Kemajuan zaman modern membawa dampak bagi kehidupan manusia, baik dampak positif maupun dampak negatif yang mendominasi. Kemajuan yang telah merambah berbagai aspek kehidupan manusia, baik itu sosial, ekonomi, budaya dan politik, menuntut individu untuk beradaptasi dengan perubahan yang terjadi secara cepat dan aman. Simbolsimbol zaman modern yang ditampilkan oleh peradaban perkotaan dengan tingkat mobilitas yang tinggi dan perubahan lingkungan yang cepat telah menciptakan kesenjangan antara manusia dengan lingkungan sosialnya. Realitas ini kemudian melahirkan berbagai gambaran tentang kondisi manusia modern yang sarat dengan persoalan fisik. Tokoh psikologi manusia, Rollo May, berpendapat bahwa manusia modern adalah manusia yang terkurung, yaitu manusia yang telah kehilangan makna hidup. Dia selalu menderita kecemasan dan tidak bisa memilih jalan hidup yang dia inginkan. Sosiolog menyebut kondisi manusia modern sebagai gejala keterasingan (Burhani, 2002).

Oleh karena itu kita membutuhkan bentuk atau sentuhan yang efektif yang mampu kembali ke dimensi manusia. Salah satunya dapat diawali dengan kegiatan dakwah Islam untuk kemanusiaan (Karim dkk, 2021). Dakwah sebagai gagasan dan gerakan yang menekankan prinsip cinta ma'ruf nahi munkar dapat memasuki spektrum aktivitas manusia yang sangat luas dan kompleks. Dakwah harus menjadi suluh dengan fungsi penyeimbang dan memberi arah pada kehidupan masyarakat. Dalam hal ini, suluh berarti penerang (Karim dkk, 2019).

Dakwah Islam adalah upaya orang-orang beriman untuk mempengaruhi dan mengajak umatnya mengikuti ajaran Islam dalam segala aspek kehidupan. Menurut Amrullah Ahmad, untuk mencapai tujuan tersebut, keimanan manusia harus diaktualisasikan dan dimanifestasikan dalam suatu sistem kegiatan yang rutin dilakukan pada dataran realitas individu dan sosial budaya dengan menggunakan metode-metode tertentu (A. Ahmad, 1985). Proses dakwah Islam untuk meraih tujuan yang diharapkan, yakni efektif serta efisien juga memerlukan komponen dakwah yang harus tertata dengan baik dan akurat. Oleh karena itu, artikel ini membahas beberapa aspek penting yang perlu 
diperhatikan ketika menjalankan misi dakwah Islam dalam kehidupan modern dan strategi dakwah yang diterapkan di era modern.

Di zaman modern ini, mengajarkan Islam (baca: dakwah) bukan lagi kewenangan seorang ulama. Di mana saja, kapan saja dan dengan cara apa saja, masyarakat bisa berdakwah. Bagaimanapun juga, dakwah merupakan tuntutan yang harus dijalankan setiap muslim disertai dengan tanggungjawab dan sepenuh hati, hingga menjadi kebiasaan yang berlanjut dari waktu ke waktu. Dakwah termasuk tugas mulia bagi setiap muslim sebgai bentuk mengikuti segala sesuatu yang diperintahkan kepada Allah dengan menyebarkan ajaran agama Allah kepada seluruh umat manusia dari kemuliaan dan ketinggian agamaNya (Puteh, 2000). Tujuan dari dakwah adalah untuk mengubah masyarakat menuju kehidupan yang lebih baik, lebih islami dan lebih sejahtera baik lahir maupun batin (Hafifudin, 1998). Tujuan dakwah seperti itu tampaknya sesuai dengan definisi komunikasi persuasif, percaya bahwa ada perubahan situasi orang lain. Perubahan yang dimaksud bukan hanya perubahan sementara, melainkan perubahan mendasar yang dilandasi oleh hati nurani dan keimanan.

Pelaksanaan dakwah berdasarkan pada Al-Qur'an, hadist, dan ijma'. Diantara ayat Al-Quran yang sering kali di jadikan landasan dakwah yaitu surat Ali' Imron: 104,

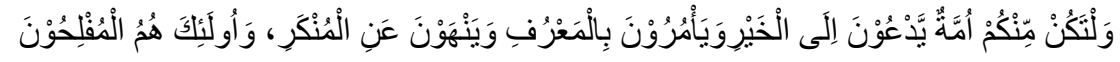

"Dan hendaklah ada diantara kamu segolongan umat yang menyeru kepada kebajikan, menyuruh kepada yang ma'ruf dan mencegah dari ynga mungkar, merekalah orang-orang yang bergantung"dan Surat Ali 'Imran; 110 " Kamu adalah umat yang terbaikyang dilahirkan untuk manusia, menyuruh kepada yang ma'ruf, dn mencegah dari yang mungkar, dan beriman kepada Allah."

Seperti dalam QS. Ali Imran: 104 di atas, bahwa kandungan makna ayat tersebut jelas menyatakan tentang kewajiaban untuk berdakwah. Terdapat kata lam amar dalam kalimat 'wal takun' membuktikan bahwa dakwah adalah kewajiban. Sedangkan" minkum "berarti fardhu kifayah, tetapi jika dilakukan oleh sekelompok orang, dakwah menjadi fardhu" ain bagi sebagian orang (Abdul, Jum"ah Amin, 1997).

Dalam Al-Qur'an, metode dakwah atau bisa disebut dengan ajakan ke jalan Allah diterapkan melalui hikmah, mau'idah hasanah dan mujdah billati hiya ahsan, yang tertuang dalam surat An-Nahl; 125,

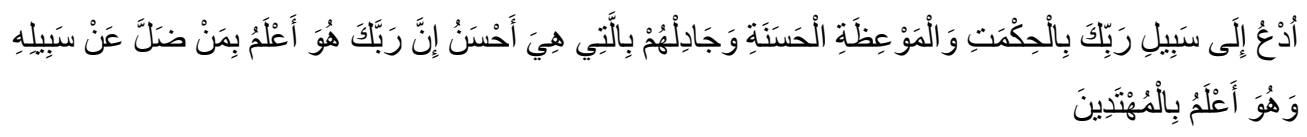

"Serulah ( manusia) kepada jalan Tuhan-mu dengan hikmah dan pelajaran yang baik dan bantahlah mereka dengan cara yang baik. Sesungguhnya Tuhanmu Dialah yang lebih mengetahui tentang siyapa yang tersesat dari jalan-Nya dan Dialah yang kebih mengetahui orang-orang yang mendapat petunjuk" Ayat ini sering kali dijadikan basis metodologi dalam menjalankan dakwah islam kepada masyarakat (Puteh, 2000).

Dakwah al-hikmah dari ayat diatas dapat diartikan sebagai seruan atau kegiatan yang mengajak dengan wajah yang arif, falsafah argumentatif, disertai dengan kesabaran 
penuh dan kekuatan, sesuai dengan ajaran dalam Al-Qur'an dan Sunnah Nubuwwah. Dakwah al-hikmah diketahui sebagai dakwah yang arif, yang selalu menyesuaikan kondisi dan situasi si mad'u. Kondisi tersebut terdapat pada keadaan melihat mad'u seperti dilihat dari tingkat pendidikan, umur, kondisi kejiwaan, budaya mad'u, dll.

Dakwah Al-Mauidzatil Khasanah memiliki banyak arti, antara lain: a. Pemberian pengertian dan nasehat yang positif, menjadi teladan (uswah), bahasa yang halus dan memotivasi. B. Keadaan hati yang baik, menyentuh jiwa serta memperbaiki segala amal perbuatan. C. Pembelajaran yang mengesankan, penjelasan, aturan, gaya bahasa menyentuh hati manusia. D. Bicaralah dengan lembut, bertahap, dengan cinta, dll. Dakwah Al-Mauidzatil Khasanah sama sekali tidak egois, gejolak emosi atau bahkan apologetik. Dakwah tersebut cenderung dilakukan kepada masyarakat secara luas. Da'i memiliki peran untuk membimbing, sahabat terdekat yang memberikan hidayah kepada mad'u.

Kemudian metode Dakwah dengan Wa-jadilhum bi allati hiya ahsan, atau dakwah yang ditempuh melalui diskusi atau diskusi dengan baik, dengan sopan santun, dengan saling menghargai, tidak sombong. Metode dakwah seperti ini digunakan untuk mad'u dolongan tiga yang memiliki kekuatan intelektual lebih unggul dari yang lain. Adapun beberapa hal yang perlu diperhatikan ketika melakukan metode ini, yakni: (1) tidak merugikan pihak lain, apalagi sampai mencemarkan nama baik. Tujuan dilakukannya metode ini untuk memperoleh pencerahan, mencari kebenaran dan kebenaran sejati bukan mencari kemenangan. (2) tujuan diskusi hanya untuk mencari kebenaran menurut ajaran Islam, tidak lebih. (3) tetap menjaga rasa hormat kepada lawan, menjaga harga diri serta menghargai lawan agar tidak tersakiti.

Metode dakwah Wa-jadilhum bi allati hiya ahsan adalah dakwah yang ditempuhlewat adanya diskusi atau diskusi yang dilalui dengan baik, dengan sopan santun, saling menghargai, tidak sombong. Metode tersebut dipakai untuk sekelompok manusia kelas tiga yang mempunyai kekuatan intelektual lebih berkelas dari yang lain. Terdapat beberapa prinsip yang perlu diperhatikan ketika menggunakan metode ini, yakni: pertama, tidak merugikan pihak lain, terlebih mencemarkan nama baik. Tujuannya bukan untuk mencari kemenangan, melainkan sebagai jalan pencerahan dan suatu kebenaran sejati. Kedua, hanya untuk menunjukkan kebenaran menurut ajaran agam Islam, tidak lebih. Ketiga, tetap mengharhai dan menghormati lawan, tetap menghormati diri sendiri dan lawan supaya tidak ada kesan merugikan dan meremehkan.

Dakwah sebagai kewajiban dapat dilakukan sesuai dengan kapasitas setiap manusia. Dakwah yang memiliki arti upaya menyeru dan mengajak seluruh manusia untuk menuju jalan Allah SWT (sistem Islam) sesuai denganajaran Islam dan spiritualitasnya secara menyeluruh, melalui kegiatan cermah, tulisan dan kegiatan akal serta tindakan, sebagai langkah mewujudkan ajaran kebaikan serta kebenaran yang luas berdasarkan dengan landasan Islam (Alhidayatillah N., 2018). Saat ini metode dan teknik dakwah yang semakin berkembang seiring dengan perubahan ruang dan waktu, namun prinsipnya tetap pada masyarakat Islam. masyarakat Islam adalah masyarakat terbuka; masyarakat di mana dakwah amar ma'rufnahi munkar dapat berkembang dan melakukan apa yang seharusnya. Berbagai upaya penyebaran dakwah sangat erat kaitannya dengan perubahan yang dialami manusia, tidak terlepas dari kemajuan ilmu pengetahuan dan teknologi yang 
memungkinkan manusia menguasai, mengelola dan memanfaatkan alam untuk kesejahteraan umat manusia. , agar dakwah Islam diterima oleh semua kalangan manusia.

Dalam proses dakwah mungkin terjadi dinamika antara penceramah dan penerima dakwah. Dinamika yang biasa terjadi tentunya bersumber dari beberapa hal, salah satunya yang sering terjadi adalah pemilihan sarana dan metode dalam berdakwah. Perkembangan teknologi yang serba up-to-date mendorong masyarakat untuk berdakwah dengan memanfaatkan teknologi dalam bentuk media online. Terkait dengan masalah tersebut, penulis menemukan beberapa penelitian sebelumnya, penelitian pertama yang berjudul Dinamika Komunikasi Islami di Media Online, majalah tersebut menganalisis dinamika komunikasi Islam yang terjadi di media online. Media online telah menjadi semacam basis dakwah Islam kontemporer, namun beberapa konten (konten) dakwah tidak memberikan informasi keislaman, sehingga diperlukan kehati-hatian dalam menerima dan memahami informasi yang disampaikan oleh media online. Majalah lainnya adalah majalah yang ditulis oleh Muhammad Rajab, dengan judul Dakwah dan Tantangannya dalam Teknologi dan Media Komunikasi. Majalah tersebut berpendapat bahwa semakin meluasnya arus informasi di seluruh dunia membuat pertukaran informasi semakin cepat dan mudah menyebar ke berbagai belahan dunia, namun hal tersebut menyebabkan negara-negara membuat sistem dalam pengelolaan media untuk menyampaikan berita atau informasi penting. Lebih lanjut, dalam wacana keagamaan kontemporer dijelaskan bahwa agama memiliki banyak dimensi dan tidak hanya mengusung tema ketuhanan, keyakinan dan keimanan (Rajab, 2014).

\section{METODE}

Jenis penelitian yang digunakan adalah kualitatif dengan pendekatan deskriptif dan studi literatur sebagai teknik pengumpulan datanya. Metode studi literature adalah serangkaian kegiatan yang berkenaan dengan metode pengumpulan data pustaka, membaca dan mencatat serta mengelola bahan penelitian. Data yang dikumpulkan dalam metode deskriptif ini nantinya bukan berupa angka-angka melainkan kata-kata dan gambar-gambar (Moleong, 2010). Adapun teknik analisis data yang digunakan dalam penelitian ini adalah mengunakan langkah-langkah reduksi data, penyajian data, verifikasi dan penegasan kesimpulan.

\section{HASIL DAN DISKUSI}

\subsection{Hasil}

Modo merupakan istilah bahasa latin dari kata 'modern'” yang artinya sekarang". Istilah tersebut sering dikaitkan dengan kehidupan yang terdapat pada masyarakat Barat yang telah mengalami tingkat industrialisasi dan teknologi maju (Gaffar, 1998). Modern adalah keadaan saat ini dimana perkembangan ilmu pengetahuan dan teknologi sangat pesat, sampai-sampai merusak tatanan, pemikiran, budaya dan perubahan sosial lainnya. Masyarakat yang dikatakan modern yaitu masyarakat yang mayoritas warganya berorientasi pada nilai-nilai budaya yang diarahkan pada kehidupan di era saat ini. Pada 
umumnya sering diidentikkan masyarakat modern dengan hidup di perkotaan, oleh karena itu dijuluki masyarakat perkotaan, meskipun tidak seluruh masyarakat modern karena tidak berorientasi pada masa kini. Karakteristik dari modernisasi ada tiga hal, meliputi: subjektivitas, kekritisan dan kemajuan.

Menurut Zakiah Drajat terdapat ciri-ciri dari modern yaitu 1) Meningkatkan kebutuhan hidup manusia. 2) Individualisme dan egoisme. 3) Persaingan dalam hidup. 4) Situasi yang tidak stabil (Daradjat, 1993). Selanjutnya, hal lain yang berkembang dari modernisme adalah munculnya mekanisme kehidupan masyarakat. Modernisme dalam masyarakat Barat berarti pemikiran, ajaran, gerakan dalam rangka mengubah pemahaman, adat istiadat, institusi terdahulu, dll, untuk menyesuaikan dengan suasana baru yang diciptakan oleh kemajuan ilmu pengetahuan dan teknologi modern. Pemikiran dan aliran ini dengan cepat memasuki bidang agama dan modernisme dalam kehidupan keagamaan Barat dengan tujuan untuk mengadaptasi ajaran yang terkandung dalam Katolik dan Protestan dengan ilmu pengetahuan dan filsafat modern. Aliran ini pada akhirnya menyebabkan munculnya sekularisme di masyarakat Barat (Zulkarnaini, 2015). Hal ini merupakan suatu konsekuensi yang logis bersumber dari teknologi sebagai akibat dari kemajuan ilmu pengetahuan modern. Ciri utama teknologi yakni sifatnya yang mekanistik dan instrumental. Hal ini berdasarkan cerminan dalam dunia industri modern yang sarat dengan kehadiran teknologi sebagai alat produksi.

Modernisme merupakan suatu proses yang berlangsung dari waktu ke waktu dan menghasilkan berbagai produk berupa gaya hidup, budaya dengan berbagai aspek lainnya. Fenomena modernisme yang diyakini sebagai pilihan tepat untuk membebaskan manusia dari situasi keterbelakangan, keterbelakangan, kemiskinan, kebodohan, meski dalam arti terbatas menunjukkan kemajuan yang cukup spektakuler, namun juga menyisakan persoalan yang cukup rumit dan kompleks. Manusia modern yang lebih maju dari masyarakat tradisional idealnya mampu berpikir dengan logika dan menggunakan bermacam-macam teknologi sebagai langkah meningkatkan kualitas hidupnya. Dengan kecerdasannya, maka manusia modern sesungguhnya harus menjadi semakin bijaksana, namun nyatanya banyak manusia yang mempunyai kualitas manusia yang lebih rendah dari kemajuan pemikiran dan teknologi yang dicapai.

Berkaitan dengan hal tersebut, Sayyid Hosein Nasr memandang bahwa akibat dari masyarakat modern yang memuja ilmu pengetahuan dan teknologi berada di pinggiran keberadaannya sendiri, menjauh dari pusat, sedangkan pemahaman agama berdasarkan wahyu meninggalkan kehidupan sekuler (Syukur, 1997). Selain itu, kegiatan berdakwah di era modern ini jelas tidak lepas dari berbagai tantangan dari non-Muslim, khususnya para sekelompok misionaris yang selalu berusaha mendoktrinkelompok yang lebih rendah atau miskin agar mengikuti keyakinan yg dianut oleh mereka dengan berbagai cara, misalnya melalui pendidikan, bantuan keuangan, dll (R. Ahmad, 2017). Kondisi seperti ini menuntut setiap manusia untuk meningkatkan keimanannya dan beradaptasi dengan perubahan yang terjadi secara cepat dan aman, sehingga menimbulkan banyak masalah karena kemajuan tersebut tidak mampu memenuhi kebutuhan dasar manusia dalam aspek nilai-nilai transenden. 
Perkembangan teknologi komunikasi, transportasi dan informasi telah membuka kesadaran baru umat manusia terhadap bidang dan dimensi kehidupan. Ruang kehidupan manusia tidak lagi terbatas pada bumi tempat ia hidup dan tinggal, tetapi juga mulai meluas ke ruang angkasa dan ke dalam semua jenis galaksi. Kemajuan-kemajuan tersebut telah membawa perubahan yang sangat besar dalam berbagai aspek tatanan kehidupan manusia, mulai dari cara berpikir, bersikap dan berperilaku. Tantangan yang mereka hadapi semakin kompleks, mereka tidak memperdulikan ruang dan waktu serta strata masyarakat, tetapi meluas ke segala bidang kehidupan dan kehidupan manusia. Kehidupan beragama umat manusia, termasuk Islam, dimanapun berada, akan dihadapkan dengan tantangan yang kurnag lebihnya sama.

Hasan Al-Banna mengatakan bahwa dakwah identik dengan Islam itu sendiri (Sufri, 2000). Oleh karena itu, segala kegiatan yang berhubungan dengan Islam dapat disebut kegiatan dakwah. Tantangan dakwah saat ini semakin kompleks, berkembangnya ilmu pengetahuan dan teknologipun menjadi pengaruh mentalitas, budaya serta perilaku masyarakat. Sehingga ide-ide yang datang dari luar Islam mudah diserap oleh masyarakat dalam kehidupannya. Oleh karena itu, argumentasi yang berlandaskan humanisme, hak asasi manusia, kebebasan dan pluralisme akan menjadi dasar bagi penyelesaian segala persoalan kehidupan. Kadang-kadang ini tampaknya menang atas hukum atau ajaran Tuhan.

Dalam konteks Islam di era modern, beberapa faktor yang menjadi penghambat kegiatan dakwah adalah: 1) Kualitas SDM, 2) Kurangnya penguasaan teknologi, 3) Keterbatasan modal, 4) Rendahnya solidaritas umat Islam, 5) Informasi dan perang teknologi. Amien Rais berpendapat bahwa terdapat beberapa efek negatif globalisasi yang disebarkan melalui dunia Barat yang cenderung berpengaruh pada kehidupan seorang Muslim juga sekaligus menjadi tantangan dakwah tersendiri di era ini, diantaranya:

1. Materialisme yang selalu kuat saat ini.

2. Ada proses individualistis. Kehidupan kolektif, persatuan, gotong royong, kini telah digantikan oleh semangat individualisme yang kuat.

3. Sekularisme selalu memisahkan kehidupan beragama dari urusan publik, karena agama hanya dinilai sebagai urusan pribadi antar individu.

4. Munculnya relativitas norma etika, moral dan moral. Oleh karena itu dalam masyarakat yang dianggap tabu, dapat dianggap dalam konteks masyarakat lain (Rais, 1998).

Peran subjek dakwah (da'i) akan sangat menentukan warna kegiatan dakwah yang dilakukan seiring dengan perkembangan peradaban yang bergulir, sehingga seseorang harus mampu memberikan motivasi untuk mencapai cita-cita tersebut. diinginkan. objektif. Oleh karena itu, tantangan da'i untuk berdakwah selalu lebih besar, ketika akses pemanfaatan teknologi informasi dan komunikasi semakin terbuka, namun di sisi lain dituntut profesionalisme lembaga dan da'i yang lebih baik, dan terberat. menggunakan media yang telah menjadi industri yang menguntungkan untuk tujuan dakwah, di balik pesan-pesan yang disampaikan. karena penggunaan teknologi informasi dan komunikasi saat ini merupakan kebutuhan yang tidak dapat diabaikan. Disinilah titik perjuangan atau jihad dalam bidang dakwah oleh lembaga-lembaga da'i atau dakwah, dahulu bangsa-bangsa berjuang menguasai wilayahnya atau memperjuangkan kemerdekaan wilayahnya, kini 
rakyat mulai berjuang dalam bidang baru, yaitu informasi, sehingga tidak dikuasai oleh mereka yang menguasai informasi (Sardar, 1996) untuk membebaskan manusia dari ciriciri kebodohan modern.

Dari segi teknologi yang digunakan, dakwah dapat kita bedakan menjadi tiga kelompok teknologi mutakhir yang digunakan, yaitu: dakwah konvensional, tele dakwah, dan e-dakwah. Beberapa perbedaan antara e-Dakwah, tele dakwah dan dakwah konvensional dalam berbagai aspek dapat dilihat pada tabel berikut ini:

Tabel 1. Perbedaan Dakwah Konvensial, Tele Dakwah, dan e-Dakwah

\begin{tabular}{|c|c|c|c|c|}
\hline No. & Aspek & Dakwah Konvensional & Tele Dakwah & E- Dakwah \\
\hline 1. & Metode & Human Touch & $\begin{array}{l}\text { Hi-tech touch } \\
\text { lebih dominan }\end{array}$ & Hi-tech touch \\
\hline 2. & Cakupan & Terbatas & Luas & Hampir tak terbatas \\
\hline 3. & $\begin{array}{l}\text { Mode } \\
\text { Interaksi }\end{array}$ & Satu tempat, satu waktu & $\begin{array}{l}\text { Berbeda } \\
\text { tempat, satu } \\
\text { waktu Beda } \\
\text { tempat, beda } \\
\text { waktu }\end{array}$ & $\begin{array}{l}\text { Beda tempat dan } \\
\text { satu waktu. Beda } \\
\text { tempat dan beda } \\
\text { waktu }\end{array}$ \\
\hline 4. & Teknologi & $\begin{array}{l}\text { Tanpa teknologi/ } \\
\text { Teknologi sederhana }\end{array}$ & $\begin{array}{l}\text { Teknologi } \\
\text { Penyiaran }\end{array}$ & $\begin{array}{l}\text { Teknologi informasi } \\
\text { (internet) }\end{array}$ \\
\hline 5. & Keahlian & Pengetahuan Agama & $\begin{array}{l}\text { Pengetahuan } \\
\text { Agama. } \\
\text { Pengatahuan } \\
\text { Brodcasting }\end{array}$ & $\begin{array}{l}\text { Pengetahuan agama. } \\
\text { Pengetahuan } \\
\text { tentang teknologi } \\
\text { informasi }\end{array}$ \\
\hline
\end{tabular}

Dari tabel diatas dapat dilihat perbedaan antara dakwah konvensional, tele dakwah dan e-Dakwah. Dimana dari masing-masing jenis dakwah tersebut memiliki masa kejayaannya masing-masing. Saat ini di era modern e-dakwah lebih mendominasi dibanding jenis dakwah lainnya. E-Dakwah merupakan suatu metode baru untuk menyampaikan misi keislaman dalam konteks agar tersebar lebih luas dan lebih besar. Dibandingkan dengan metode dakwah lainnya e-dakwah memiliki cakupan mad'u yang lebih luas sebab e-dakwah menggunakan teknologi informasi (internet). Dimana hampir seluruh masyarakat menggunakan internet. Hal tersebut berarti bahwa digunakannya edakwah tidak menutup kemungkinan bahwa jangkauan dari proses dakwah akan meluas sampai kesemua titik. 


\subsection{Strategi Dakwah di Era Modern}

Suatu pendekatan memunculkan strategi yang semuanya merupakan jalan untuk mencapai tujuan yang telah ditetapkan. Setiap strategi menggunakan metode yang berbeda dan setiap metode memerlukan teknik, yaitu cara yang lebih spesifik dan operasional. Selanjutnya, setiap teknik memerlukan taktik, yaitu bentuk teknik yang lebih spesifik (Mahmuddin, 2016). Strategi secara simultan membutuhkan metode, teknik, sarana dan taktik yang diperlukan. Dakwah dapat berfungsi dengan baik dan efektif, jika tugas-tugas dakwah dilaksanakan sesuai dengan rencana dan pengaturan yang telah ditetapkan oleh pengambil kebijakan (Mahmuddin, 2016). Selanjutnya tugas dakwah dilaksanakan secara terencana dan berkesinambungan.

Kegiatan dakwah harus menggunakan strategi yang mampu menjawab semua aspek kehidupan manusia, serta diperlukan untuk mengatasi dan menetralisir gejolak sosial yang timbul. Itulah sebabnya strategi merupakan perpaduan antara perencanaan dan pengelolaan dakwah untuk mencapai suatu tujuan. Islam dikenal sebagai agama dakwah, bisa juga disebut sebagai agama yang memiliki misi khusus, yaitu agama yang harus menjangkau umat manusia secara keseluruhan.

Fenomena lain yang muncul adalah kendala yang dihadapi oleh para da'i saat ini berhadapan dengan manusia yang multikultural, beragam suku, pekerjaan dan profesi yang semuanya profesional dan juga menghadapi manusia kontemporer dan kekinian. Masalah kontemporer mulai merambah kehidupan manusia, baik di perkotaan maupun pedesaan, dan telah merambah semua aspek kehidupan, termasuk umat Islam. Pengaruh kehidupan modern mendorong umat Islam untuk lebih agresif dalam mengikuti arus perubahan, baik orang tua maupun remaja maupun anak-anak. Permasalahan tersebut juga telah memasuki sistem dakwah yang sedang dikembangkan oleh para ilmuwan da'i dan dakwah di Indonesia.

Dakwah kontemporer adalah dakwah yang menggunakan struktur teknologi modern dengan tiga indikator, yaitu da'i menggunakan teknologi modern, materi dakwah kontemporer, dan da'i menggunakan media kontemporer (Mahmuddin, 2016). Pola kehidupan modern, banyak manusia yang terjebak dalam sentuhan teknologi yang cenderung mengubah keimanan kepada Tuhan dan menuju kepada pendewaan teknologi yang menyebabkan lemahnya keimanan.

Syed Muhammad Naquib al-Attas menyatakan bahwa ada banyak tantangan yang muncul di tengah kesalahan manusia sepanjang sejarah, tetapi mungkin tidak ada yang lebih serius dan lebih merusak manusia daripada tantangan yang ditimbulkan oleh peradaban Barat saat ini (Al-Attas, 2011). Untuk dapat menjawab tantangan tersebut dan memahami tanda-tanda berakhirnya era transisi saat ini, perlu dipahami indikasi perubahan budaya dan sosial-keagamaan yang mendasar dalam upaya membentuk dunia baru di era globalisasi. Dalam berdakwah, diperlukan pengenalan yang akurat dan tepat tentang realitas kehidupan manusia yang sedang dan benar-benar terjadi dalam hidup Anda. Semua komponen dan aspek yang menentukan keberhasilan dakwah harus ditata secara profesional dan disesuaikan dengan kondisi mad'u untuk menghasilkan paket dakwah yang benar-benar mampu meningkatkan dan meningkatkan semangat dan kesadaran yang tulus. dalam memperbaharui nilai-nilai ajaran Islam. 
Dakwah bukan hanya retorika, tetapi harus mampu menjadi contoh tindakan sebagai pengembangan dakwah yang sebenarnya (Al-Attas, 2011). Untuk mencapai keberhasilan dakwah, pesan-pesan dakwah harus diubah oleh retorika menjadi kenyataan. Dakwah harus mencakup tindakan nyata seperti melindungi hukum, membantu orang kaya dengan orang miskin, menegakkan keadilan, dll. Masyarakat membutuhkan tindakan yang lebih nyata dari sekedar ceramah. Nabi, bahkan dalam keteladanannya dalam berdakwah, selalu menunjukkan perkataan dengan perbuatan. Nabi tidak hanya hidup dalam doa dan dakwah, tetapi juga melakukan tindakan sosial (Al-Attas, 2011).

Strategi dakwah ditentukan oleh kondisi objektif komunikator (mad'u) dan kondisi lingkungan pada saat proses itu berlangsung. Sementara itu, isi atau substansi pesan ditentukan oleh relevansi atau kecukupan isi pesan dengan kondisi subjektif mad'u, yaitu kebutuhan atau masalah mereka. Relevansi antara isi pesan dakwah dengan kebutuhan tersebut harus dimaknai sebagai kesopanan yang proporsional, dipahami sebagai pemecahan masalah atau pemuasan kebutuhan yang tidak bersumber dari realisasi, tetapi yang dapat mengarahkan atau mendekatkan objek. dari dakwah ke tujuan dakwah itu sendiri, dan bukan sebaliknya.

Strategi dakwah harus selalu memperhatikan realitas yang sebenarnya. Jika realitas kehidupan itu beraneka ragam dan tunduk pada perubahan yang konstan, maka strategi juga harus terbuka yang memungkinkan terjadinya perubahan dan penyesuaian secara terus menerus, sehingga kegiatan dakwah dapat mencapai tujuannya. Strategi dakwah Islam yang dilaksanakan bukanlah untuk melawan perubahan, karena perubahan tidak dapat dilawan dengan kekuatan apapun, tetapi untuk mendorong perubahan menuju kualitas moral yang lebih baik. Lembaga keagamaan harus bersinergi meningkatkan kepekaannya untuk menyikapi proses perubahan yang menyimpang dari nilai-nilai universal (Puteh, 2000). Dalam pengertian ini, strategi dakwah dirancang untuk lebih menekankan upaya pemberdayaan masyarakat dalam segala aspek kehidupan, dibutuhkan dakwah yang berorientasi pada sosial budaya. Karena strategi dakwah yang berkembang pada zaman Rasulullah termasuk dalam gerakan menuju adanya transformasi sosial. Oleh karenanya, dakwah digambarkan sebagai adanya gerakan pembebasan dari suatu eksploitasi, kemudian dominasi, serta penindasan dan ketidakadilan dalam segala aspeknya (Puteh, 2000).

Strategi dakwah ke depan harus memiliki beberapa agenda, antara lain:

1. Mendasarkan proses dakwah pada sisi kepentingan oleh masyarakat.

2. Mengintensifkan pola hubungan dan terlibatnya masyarakat.

3. Fasilitasi komunitas sehingga Anda dapat memecahkan masalah Anda dan mencapai transformasi sosial yang Anda inginkan.

4. Melakukan dakwah sebagai sarana pendidikan dan pengembangan potensi masyarakat.

Dai juga dapat memanfaatkan kecanggihan teknologi informasi dan komunikasi dalam berdakwah sebagai salah satu strateginya, karena media televisi dan kepentingan media memiliki pengaruh langsung yang sangat kuat terhadap penggunanya (Puteh, 2000). Karena masyarakat saat ini tidak hanya mengandalkan ulama sebagai satu-satunya sumber untuk memperoleh ilmu agama. Orang dapat menggunakan telepon seluler dan 
memasukkan Internet sebagai sarana yang mudah dan praktis untuk menemukan berbagai topik keagamaan, dari topik kecil yang berkaitan dengan ibadah hingga topik yang rumit, seperti untuk orang-orang kudus.

Internet telah menjadi perpustakaan raksasa dimana terdapat banyak artikel, buku, majalah, foto dan lainnya dalam bentuk elektronik didalamnya. Dimana setiap orang dapat mengakses perpustakaan tersebut kapan saja, di mana saja (Rodhin, 2011). Internet mampu mengubah perilaku massa ke arah yang mereka inginkan. Internet juga dapat menampung berbagai media dakwah lainnya, seperti lisan, tulisan, audiovisual dan dakwah gambar. Dakwah tidak harus dilakukan secara formal. Dunia seni, budaya, pariwisata, hiburan dengan segala pernak-perniknya juga bisa dijadikan sarana dakwah. Pada dasarnya, bahkan para ulama kuno menggunakan seni sebagai alat untuk berdakwah kepada masyarakat. Hal ini disertai dengan pemahaman tentang budaya masyarakat setempat. Inilah yang membuat Islam begitu mendarah daging di hati seluruh umat Islam di Indonesia (Republika.co.id, 2021). Selanjutnya, pariwisata saat ini sedang diperbaharui menjadi wisata religi dan halal. Dimana jenis pariwisata ini merupakan pariwisata yang berperan di era modern ini. Karena tidak jarang masyarakat saat ini sangat mengapresiasi hal-hal yang dapat menunjukkan eksistensinya di media sosial. Sehingga dakwah dapat berperan dalam dunia pariwisata untuk menyebarkan ajaran Islam.

Selain strategi di atas, keberhasilan dakwah dalam kehidupan modern juga didukung oleh kualitas da'i yang kompeten. Da'i harus mempunyai komitmen mengesakan Tuhan (tauhid), istiqamah dan jujur, berpandangan jernih, berpandangan keislaman, memiliki kemampuan memadukan dakwah bi al-lisan dengan dakwah bi al-hal, sesuai dengan perkataan dengan fakta, di atas semuanya adalah paham dan sekte, berpikir strategis, memiliki kemampuan analisis interdisipliner, tahu bagaimana berbicara sesuai dengan kemampuan masyarakat.

\section{KESIMPULAN}

Dakwah dalam arti paling sempit adalah memanggil dan mengajak seseorang atau sekelompok orang untuk mengamalkan ajaran Islam. Sementara itu, arti yang lebih luas dakwah bisa dipahami sebagai upaya peningkatan kualitas sumberdaya manusia, pengentasan kemiskinan, memerangi kebodohan dan keterbelakangan, serta pembebasan. Dalam kehidupan modern, dakwah harus berorientasi kepada mad'u dengan pendekatan "bil hikmah wal mauizah hasanah dan dengan pemanfaatan media (bi al-tadwin). Langkah tersebut juga dimbangi dengan para da'i -baik individu maupun kelompok yang berkualitas, mempunyai pengetahuan serta wawasan yang luas, menguasai pesan atau materi dakwah, metode, dan media yang relevan dengan melihat kondisi dan situasi pada kemajuan masyarakat modern yang sedang dihadapinya. Berdasarkan penelitian dapat disimpulkan bahwa masih banyak ulama yang masih melakukan dakwah dengan cara konvensional. Di zaman modern dakwah diharuskan mampu mengikuti perkembangan zaman dalam penyebarannya, yaitu melalui media social. Dimana hampir seluruh kalangan masyarakat mengenal internet dan media sosialnya maka jika dakwah menampakkan diri dalam kemajuan teknologi di zaman modern ini dakwah akan menjadi awam bagi masyarakat. 
Oleh karena itu dakwah perlu menerapkan e-dakwah, yaitu pelaksanaan dakwah melalui bantuan teknologi informasi, terutama internet. Dimana internet ini adalah hal yang sudah sangat awam bagi masyarakat.

\section{REFERENSI}

Abdul, Jum'ah Amin, A. (1997). Ad-Dakwah, Qawā'id Wa Us\}ūl Fiqih Dakwah; Prinsip dan Kaidah Asasi Dakwah Islam.

Ahmad, A. (1985). Dakwah Islam dan Perubahan Sosial. PLP2M.

Ahmad, R. (2017). Reformulasi Konsep Dakwah Di era Modern (Kajian tentang dakwah terhadap Ahl Al-Kitab). Komunida: Media Komunikasi Dan Dakwah, 6(1), 107-116.

Al-Attas, S. M. N. (2011). Islam and Sekularisme. PIMPIN.

Alhidayatillah N. (2018). Dakwah Dinamis Di Era Modern (Pendekatan Manajemen Dakwah). An-Nida', 41(2), 265-276.

Burhani, A. N. ( ed ). (2002). Manusia Modern Mendamba Allah Renungan Tasawuf Positif. Hikmah.

Daradjat, Z. (1993). Peranan Agama dalam Kesehatan Mental. Panji Mas Agung.

Gaffar, A. (1998). Modern dan Islam: Dua kutub yang Bertentangan dalam AI-Qur'an dan Tantangan Modernitas. 1998.

Hafifudin, D. (1998). Dakwah Aktaual. Gema Insani Press.

Karim, A., Adeni, A., Fitri, F., Fitri, A., Hilmi, M., Fabriar, S., \& Rachmawati, F. (2021). Pemetaan untuk strategi dakwah di kota semarang menggunakan pendekatan data mining. Jurnal Dakwah Risalah, 32(1). doi:http://dx.doi.org/10.24014/jdr.v32i1.12549.

Karim, A., Suharno, Y., \& Arwani, W. (2019). Pemberdayaan Sekolah Islam untuk Meningkatkan Kompetensi Profesionalisme Guru di Kabupaten Semarang. Jurnal Ilmu Dakwah, 39(1), 91-100. DOI : 10.21580/jid.v39.1.4421.

Mahmuddin. (2016). Aplikasi Dakwah Kontemporer di Bulukumba (Upaya Menangkal Radikalisme Agama). Jurnal Al Ulum, 16, 2.

Moleong, L. J. (2010). Metodologi Penelitan Kualitatif. Remaja Rosdakarya.

Puteh, M. J. (2000). Dakwah di Era Globalisasi: Strategi Menghadapi Perubahan Sosial. Pustaka Pelajar.

Rais, A. (1998). Tauhid Sosial. Mizan.

Rajab, M. (2014). Dakwah Dan Tantangannya Dalam Media Teknologi Komunikasi. Jurnal Dakwah Tablig, 15.

Republika.co.id. (2021). Kesenian jadi Media Dakwah Indonesia. Republika.Co.Id.

Rodhin, R. (2011). Internet dalam konteks perpstakaan. Pustakaloka, 3(1), 1-19.

Sardar, Z. (1996). Tantangan Dunia Islam Abada 21 Menjangkau Informasi Terj. Priyono. Mizan.

Sufri, S. N. C. (2000). Dakwah Dalam Presfektif Hasan Al- Banna. Al-Jami'ah Journal of Islamic Setudies, 38(2).

Syukur, H. M. A. (1997). Zuhud di Abad Modern. Pustaka Pelajar.

Zulkarnaini. (2015). Dakwah Islam Di Era Modern. Jurnal Dakwah Risalah, 26(3), 151-158. 